\title{
LEGAL PROTECTION OF THE RIGHT TO INDICATION OF ORIGIN IN INDONESIA
}

\author{
MUH ALI MASNUN \\ Law Department \\ Universitas Negeri Surabaya \\ Surabaya, Indonesia \\ alimasnun@unesa.ac.id
}

\begin{abstract}
The purpose of this study is to analyze the form of legal protection rights for indications of origin in Indonesia based on Law Number 20 of 2016 concerning Trademarks and Geographical Indications (Trademark and GI Law). Legal protection rights for indications of origin are inseparable from consideration of the economic value inherent in a property. Indications of origin are different from geographical indications, indications of origin are signs that indicate the origin of goods or services that are not identical to natural (geographical) factors. This research is a normative juridical using primary legal materials and secondary legal materials, as well as using prescriptive analysis methods. The results of the study show that legal protection can be provided in the form of preventive and repressive legal protection, however, the legal protection regulation of rights for indications of origin in Indonesia are still relatively very low. Protection of rights for indications of the origin arises with a declarative system that cannot be separated from the rights to the trademark. The right to the trademark is a prerequisite for being able to declare the right to an indication of origin. The period of protection of rights for indications of the following ten years of protection of trademark and can be extended again. Transfer of rights to indications of origin is impossible to do because it is attached to the rights to the trademark and is different from the non-transferability as a geographical indication. Violation of rights for indications of origin can be in the form of use of indications of origin by non-registered users of trademark has been registered with indication of origin. The firmness of the government to provide legal protection in the form of statutory rights for indications of origin is an absolute necessity. The government must be present to provide a regulation as a consequence of the legal state, which means that in carrying out all tasks and activities, it must be based on applicable law.
\end{abstract}

Keywords: Legal Protection, Indication of Origin, Indonesia 


\section{INTRODUCTION}

The activity of trading goods and / or services is an absolute requirement for every human being to complement each other. Trade arises since humans were not able to fulfill their needs by bartering, using a medium of exchange commonly known as money to the level of development of trade using bitcoin. The development of trade activities has undergone a dynamic change, this is an implication of the increasingly widespread impact of globalization, especially in the fields of technology and information. The global trade era can develop well if there is a good business competition. In this context the sign of origin of goods and / or services is relatively enough crucial when there is the potential for unhealthy business competition to emerge, including in this case Indonesia as an archipelago that has products of goods and / or services from regions of various types which shows where the goods and / or services originated from.

Protection of the origin of goods and / or services is regulated in Law Number 20 of 2016 concerning Trademarks and Geographical Indications (Trademark and GI Law). The basic arrangements for protection are contained in the consideration that to further improve services and provide legal certainty for the world of industry, trade and investment in facing local, national, regional and international economic developments.

The Trademark and GI Laws regulate geographical indications and rights to indications of origin which are distinguished in terms of the Act. The terminology of geographical indications seems to be more familiar in various conversations or references in Indonesia. Geographical indications in the general provisions of Article 1 point 6 of the Trademark and GI Law are defined as "a sign indicating the origin of an item and / or product due to geographical factors including natural factors, human factors or a combination of these two factors giving reputation, quality, and certain characteristics of the goods and / or products produced." These definitions provide several characteristics which are highlighted, among others: signs, origin of goods, natural factors, human factors, reputation, quality, and certain characteristics. Signs as geographical indications usually consist of the 
name of the product origin, but can also consist of symbols or naming directly pointing to the place of origin of the product. ${ }^{1}$

How is the system of protection, scope, subject of the applicant, the period of protection, the possibility of transferring rights, violations of geographical indications set out in the Trademark and GI Law which contradict the arrangement of indications of origin. The indications of origin in the Trademark and IG Law are not clearly defined as geographical indications, however, some indications of origin can be found in Article 63 and Article 64: "Indication of origin is protected without going through registration obligations or declaratively as a sign indicating the origin of goods and / or services that are correct and used in trade." "Indication of origin is a characteristic of the origin of goods and / or services that are not directly related to natural factors." These characteristics include signs, the origin of an item and / or service, not related to natural factors.

Indications of origin arrangement in the opinion of the author is still relatively very limited to provide protection from legal aspects. The definition of origin is not explained in general provisions, even though the regulation provides guidance in interpreting the following articles in the Trademark and GI Law. The scope of protection, protection systems, protection periods, subjects who can have rights to the indications of origin, some potential emergence of other questions related to the arrangement of indications that will have implications arise a big question how the legal protection rights for indications of origin in Indonesia. There is a possibility that the right of original indication is more from the quantitative side than the geographical indication which indeed requires that there must be registration and there are geographical (natural) factors. ${ }^{2}$ Protection of this matter is inseparable from consideration of the economic value inherent in a

Daniel F Aling, Sistem Perlindungan Indikasi Geografis sebagai Bagian dari Hak Kekayaan Intelektual di Indonesia, Karya Ilmiah, Universitas Sam Ratulangi, Manado, 2016 p.1

2 The Geographical Indication has been registered in Indonesia per September 201867 GI. 
property. ${ }^{3}$ These economic values can improve welfare and profits for the local community. ${ }^{4}$

Table 1.1

Comparison Arrangement Rights Protection of Geographical Indications and Rights to Indication of Origin

\begin{tabular}{|c|c|c|c|}
\hline No & About & Indication of Geographical & $\begin{array}{l}\text { Indication of } \\
\text { Origin }\end{array}$ \\
\hline 1. & Definition & $\begin{array}{l}\text { a sign which indicates the origin of } \\
\text { goods and / or products because of } \\
\text { the geographical environment, } \\
\text { including natural factors, human } \\
\text { factors or a combination of both } \\
\text { factors it gives reputation, quality } \\
\text { and certain characteristics to the } \\
\text { goods and / or products produced. }\end{array}$ & $\begin{array}{l}\text { Indication of } \\
\text { origin is a } \\
\text { characteristic of } \\
\text { the origin of goods } \\
\text { and / or services } \\
\text { that are not } \\
\text { directly related to } \\
\text { natural factors. }\end{array}$ \\
\hline 2 & Scope of & $\begin{array}{l}\text { goods, can be: } \\
\text { 1. Results of natural resources } \\
\text { 2. Handicrafts; } \\
\text { 3. Industrial products. }\end{array}$ & $\begin{array}{l}\text { Goods and / or } \\
\text { services }\end{array}$ \\
\hline 3 & $\begin{array}{l}\text { Protection } \\
\text { System }\end{array}$ & $\begin{array}{l}\text { Constitutive system/first to file } \\
\text { system, meaning that the right to } \\
\text { geographical indication / legal } \\
\text { protection will be given when the } \\
\text { geographical indication has been } \\
\text { registered. }\end{array}$ & $\begin{array}{l}\text { declarative system, } \\
\text { meaning that the } \\
\text { right of origin / } \\
\text { legal protection } \\
\text { arises in line with } \\
\text { the manifestation } \\
\text { of the object and } \\
\text { not through } \\
\text { registration. }\end{array}$ \\
\hline 4 & $\begin{array}{l}\text { Subjects/ } \\
\text { Applicants }\end{array}$ & $\begin{array}{l}\text { a. Institutions that represent the } \\
\text { community } \\
\text { b. Government provincial or district / } \\
\text { city }\end{array}$ & $\begin{array}{l}\text { not regulated yet } \\
\text { (who can declare) }\end{array}$ \\
\hline
\end{tabular}

3 Trias Palupi Kurnianingrum, Perlindungan Hak Ekonomi atas Indikasi Geografis, Jurnal Negara Hukum, Vol 7, 2016 p. 1

4 Winda Risma Yessiningrum, Perlindungan Hukum Indikasi Geografis sebagai Bagian Hak Kekayaan Intelektual, Jurnal Kajian Hukum dan Keadilan IUS, p.43 


\begin{tabular}{|c|l|l|l|}
\hline 5 & Period & $\begin{array}{l}\text { Unlimited as long as the quality or } \\
\text { reputation is still intact. }\end{array}$ & Not regulated yet \\
\hline 6 & $\begin{array}{l}\text { Transfer of } \\
\text { non- } \\
\text { transferable } \\
\text { rights }\end{array}$ & Non transferable & Not regulated yet \\
\hline 7 & Violations & $\begin{array}{l}\text { a. Use of geographical indications } \\
\text { that do not requirement the GI } \\
\text { Description Document } \\
\text { b. Use of GI signs that can mislead } \\
\text { the public in connection with the } \\
\text { geographical origin of the item; } \\
\text { Use of GI by registered GI Users }\end{array}$ & Not regulated yet \\
\hline
\end{tabular}

\section{RESEARCH METHODS}

The type of research in this study is normative juridical. Normative legal research is a process to find a rule of law, legal principles, and legal doctrines faced. ${ }^{5}$ This study uses the statue approach. The legal approach is carried out by examining all the rules and regulations that relate to the legal issues being addressed. ${ }^{6}$ Legal materials used are in the form of primary legal material and secondary legal material. Primary legal material consists of Trademark and GI Law. Secondary legal material consists of books, journals, research results that are relevant to the research of the author. The legal material analysis technique used in this study is to analyze prescriptive legal materials, namely to formulate and submit guidelines and rules that must be obeyed by legal and dogmatic practices of law.

\section{RESULTS AND DISCUSSION}

The existence of law cannot be separated from society, because law is a means to create a sense of peace and security (protection). Law is protection of human interests in the form of norms or rules. Law as a set of rules or rules containing content that is general and normative, general and applies to everyone,

5 Peter Mahmud Marzuki, Penelitian Hukum, Surabaya: Kencana, 2011 p. 35

6 Ibid 
and normative because it determines what may and may not be done, and determine how to implement compliance with the rules. ${ }^{7}$

Satjipto Rahardjo said that legal protection is an effort to protect one's interests by allocating a power to him to act in the context of his interests. ${ }^{8}$ Furthermore, Satjipto Rahardjo gave the opinion that legal protection is to provide protection for human rights that are harmed by others and that protection is given to the community in order to enjoy all the rights granted by law. ${ }^{9}$ Thus legal protection can be interpreted that the law must have a role in providing protection for human interests, especially human rights (HAM).

The right to indication of origin as one of the declarative inherent rights should be able to provide protection to people who have interests, community / public, especially in relation to aspects of business (business). This is in line with Nathan Roscoe Pound's idea that to fulfill his role classify the interests that must be protected by law, namely: ${ }^{10}$

a. Public interest

b. Public interest (social interest), which is divided into five, namely:

1. The importance of peace and order;

2. Protection of social institutions;

3. Prevention of moral decline;

4. Prevention of rights violations;

5. Social welfare.

c. Private interest

Based on the theory of legal protection, legal protection consists of 2 (two) namely preventive legal protection and repressive legal protection. Preventive legal protection can be interpreted as a form of protection in the form of efforts to prevent from occurring a violation of a law. Repressive legal protection can be interpreted as a form of protection as an effort to prevent violations.

\footnotetext{
Sudikno Mertokusumo, Mengenal Hukum Suatu Pengantar, Liberty, Yogyakarta, 2010 p. 39

Satjipto Rahardjo, Sisi-sisi Lain dari Hukum di Indonesia, Kompas, Jakarta, 2003, p. 121

Satjipto Rahardjo, Ilmu Hukum, Citra Aditya Bakti, Bandung, 2000, p. 55

Sudikno Mertokusumo, Op. Cit, p. 44
} 
Preventive legal protection in this context, the author will analyze how the formulation of regulatory indications as long as it is able to provide legal protection (both formally and material). The arrangement of indications of origin in the Trademark and GI Law is only regulated in 3 Articles, namely:

Article 63: "Indications of origin are protected without going through registration obligations or declaratively as a sign indicating the origin of an item and / or service that is correct and used in the trade".

Article 64: "Indication of origin is a characteristic of the origin of goods and / or services that are not directly related to natural factors".

Article 65: "Further provisions regarding indications of origin as referred to in Article 63 and Article 64 are regulated by Ministerial Regulation".

Definitions relating to indications of origin are not found at all from the Trademark and GI Law, so that the arrangement seems half-centered, only with Article 64 helping to interpret that indications of origin are characteristic of goods and / or services not directly related to natural factors.

In the explanation of Article 64 of the Trademark and GI Law, the indication of origin is not the same as the geographical indication because the indications of origin only identify the origin of the goods produced that are not related to natural factors. Examples of Nikon-the trademark cameras originating from Japan were also given by their factory in China through a license and the Chinese product was written in Made in China. This Made in China label is an indication of origin. Can the label (indication of origin) only be interpreted in the context of the license? In the opinion of the author, this is not absolutely valid, moreover the explanation in legislation is not binding as the norm in articles which do have binding powers. The use of an indication label (sign) as long as it is very open may not have to go through the transfer of license rights, especially seeing the condition of Indonesia as a large country, has the potential to produce which shows the origin of goods and / or services. This context, the law can be used to realize protection that is not only adaptive and flexible, but also predictive and anticipatory. 
Furthermore, the indication of origin is always attached to the existing trademark, whether the trademark must be registered first or not, which in turn arises the right to the trademark so that it can make an indication of origin (declarative system). This regulation needs to be emphasized so that there is legal certainty, because maybe the trademark has not been registered, but indicates the origin of the goods and / or services produced. Regarding these problems, the solution to this problem is by using an analogy to the arrangement of geographical indications. Arising of the right to a geographical indication is to register the geographical indication or commonly known as a constitutive system. In principle, the right to an indication of origin is in line with the manifestation of the object rather than through registration, different from protecting constitutive geographical indications and requiring registration, however, needs to be noted that the right to indication of inherent rights to the trademark, so that the right to indications of origin are always preceded by the rights to the trademark or otherwise the rights to the trademark are risen, could be followed (not always) rights to the indication of origin. If the right to indicate the origin of the trademark that has not been registered, it is likely that there will be difficulties in obtaining legal protection, mainly related to proof at the trial if there is a dispute in the future.

Other problems that are related to subjects who have the right to indication of origin, in the Trademark and GI Law, have not been regulated by anyone / subject who can retain the right to indication of origin when there is another person who passing off. That problem could be given a solution using the previous discussion, that the arising of the right to an indication of the inherent origin of the right to the trademark so that the person who has / the subject who can retain the right to indicate the origin is a registered legal subject.

The basic concept in intellectual property rights generally provides guidance that protection is given to intellectual property with the provision that there is a limitation of time (period). The right to the trademark has a protection limit for 10 years, then it can be extended to the extent that it can meet the provisions of the legislation. Protection of geographical indications with unlimited, with 
prerequisite still can maintain the quality and reputation of the goods produced. Trademark and GI Law is not regulate yet right to indication of origin about period, simple logic that could be used as the basis for determining the period of protection is as the right to the trademark, due to the rising of the right to indication of inherent rights to the trademark, so that the legal protection period for the right to indication origin is 10 years and can be extended as long as the brand is registered or in other words the period of protection of rights for indications of following protection given rights to the trademark, the difference is that in the declarative system.

A declarative system that arises in line with the object's embodiment needs to be carried out techniques how to prove that having right to geographical indication is a certain law, then in the right of indication there are several techniques used as the basis of the use, including through a self delivery box (SDB). It means that we send a sign of the right to the indication of origin by attaching to the goods and / or products produced then sending by expedition to our own address. This delivery date mark / stamp could be used as our basis as the date of birth of the right to an indication of origin. The package does not need to be opened but is stored properly as a basis if one day there is a dispute over the right to indication of origin, then the package of shipment is used as proof of when the right to indicate that we have started using the goods and / or products we produce.

The transfer of rights in intellectual property rights is the transfer of the right to produce, use, duplicate the rights inherent in the goods and / or services. Intellectual property rights generally state that these rights can be transferred for example through licenses, endowments or grants. The right to the indication of origin that is inherent where the location of the production of goods and / or services is made, it is not possible for the right to the indication of origin to be transferred by any method and method. This reason is quite strong, because the inherent right to the indication of origin with the right to the trademark that could be transferred is the right to the trademark. The right to indication of origin is not transferable different with the right to geographical indication because it is 
influenced by natural factors in an area, so that if it is transferred potential / may have quality / reputation that is not the same as where the original geographical indication originated produced.

Violations about indication of origin are possible carried out by other parties who have interests. The lack of regulation on violation of rights for indications of origin in the Trademark and GI Law, in the opinion of the author, is a matter that needs to be considered as an important concern when the law is born to protect the rights inherent in legal subjects. These violation provisions can be used as a basis in the (formal) process. In connection with this, the categorization of rights violations for indications of origin can use the parameter "usage indication of origin of non-registered user of trademark registered with indication of origin".

Repressive legal protection in the context of this study the author analyzes how the legal remedies if there has been a violation of the right to an indication of origin. Article 108 of the Trademark and GI Law which stipulates that the implementing regulations of this Law must be stipulated no later than 2 (two) years from the promulgation of this Law, including in this case the ministerial regulation related to the original indication as ordered by Article 65 of the Trademark and GI Law. The Trademark and GI Law was promulgated on November 25, 2016, if there are 2 (two) years limit of implementing regulations (beleid) until the author composes this article means just a few days. Originally the regulation contained in full all matters relating to indications of origin. Thus, in general of results of the analysis set out in Table 1.2

Table 1.2

Protection Arrangement Rights to Indication of Origin

\begin{tabular}{|c|l|l|}
\hline No. & \multicolumn{1}{|c|}{ About } & \multicolumn{1}{c|}{ Indication of Origin } \\
\hline 1 & Definitions & $\begin{array}{l}\text { indication of origin is characteristic of } \\
\text { the origin of goods and / or services that } \\
\text { are not directly related to natural factor }\end{array}$ \\
\hline 2 & Scope & Goods and / or services \\
\hline
\end{tabular}




\begin{tabular}{|c|l|l|}
\hline 3 & System protection & $\begin{array}{l}\text { System declarative, means the right } \\
\text { indication of origin / legal protection } \\
\text { arising in accordance with the } \\
\text { embodiment of the object and not } \\
\text { through registration, be }\end{array}$ \\
\hline 4 & Subject / Applicant & $\begin{array}{l}\text { Following the rights holder for the brand } \\
\text { attached to the indication of origin }\end{array}$ \\
\hline 5 & Period & $\begin{array}{l}\text { in accordance with the rights to the brand } \\
\text { registered }\end{array}$ \\
\hline 7 & Violations & $\begin{array}{l}\text { Cannot be transferred } \\
\text { Use of indications of origin by non- } \\
\text { registered users of brands registered with } \\
\text { indication of origin }\end{array}$ \\
\hline
\end{tabular}

In general, the legal protection of rights for indications of origin in Indonesia is still relatively limited. Legal protection as conveyed by Satjipto Rahardjo as a form of protection of human rights has become a necessity that needs to be immediately regulated comprehensively. The firmness of the government to provide legal rights protection for indications of origin is an absolute necessity. The government must present to provide a regulation as a consequence of a legal state which means that in all matters carrying out its duties and activities must be based on applicable law, so that legal protection as Roscoe Pound's opinion says that the law must protect public interest, public interest and private interest.

\section{CONCLUSION}

Legal protection could be given in the form of preventive and repressive legal protection, however the legal protection arrangements of rights for indications of origin in Indonesia are still relatively very subtle. Protection of rights for indications of the origin of being born with a declarative system that cannot be separated from the rights to the trademark. The right to the trademark is a prerequisite for being able to declare the right to an indication of origin. The period of protection of rights for indications of the following ten years of protection of trademark rights and can be extended again. Transfer of rights to 
indications of origin is impossible to do because it is attached to the rights to the trademark and is different from the non-transferability as a geographical indication. Violation of rights for indications of origin can be in the form of use of indications of origin by non-registered users of trademark registered with indication of origin.

The firmness of the government to provide legal rights protection for indications of origin is an absolute necessity. The government must present to provide a regulation as a consequence of a legal state which means that in all matters carrying out its duties and activities must be based on applicable law, so that legal protection as Roscoe Pound's opinion says that the law must protect public interest, public interest and private interest. The most concrete assertiveness is to issue implementing regulations (beleid) regarding the right to an indication of origin as soon as possible, without reducing the substance of the regulation.

\section{BIBLIOGRAPHY}

F Aling, Daniel, 2016 Sistem Perlindungan Indikasi Geografis sebagai Bagian dari Hak Kekayaan Intelektual di Indonesia, Karya Ilmiah, Universitas Sam Ratulangi, Manado

Kurnianingrum, Trias Palupi, 2016, Perlindungan Hak Ekonomi atas Indikasi Geografis, Jurnal Negara Hukum, Vol 7.

Marzuki, Peter Mahmud, 2011, Penelitian Hukum, Surabaya: Kencana.

Mertokusumo, Sudikno, 2010, Mengenal Hukum Suatu Pengantar, Liberty, Yogyakarta.

Rahardjo, Satjipto, 2000 Ilmu Hukum, Citra Aditya Bakti, Bandung. 2003 Sisi-sisi Lain dari Hukum di Indonesia, Kompas, Jakarta.

Yessiningrum, Winda Risma, Perlindungan Hukum Indikasi Geografis sebagai Bagian Hak Kekayaan Intelektual, Jurnal Kajian Hukum dan Keadilan IUS. 